\title{
Combustion Synthesis Ironmaking: Investigation on Required Carbon Amount in Raw Material from the Viewpoint of Adiabatic Flame Temperature Calculation
}

\author{
Keisuke Abe ${ }^{1, *}$, Ade Kurniawan ${ }^{2}$, Masafumi Sanada $^{2}$, Takahiro Nomura ${ }^{1}$, and Tomohiro Akiyama ${ }^{1}$ \\ ${ }^{1}$ Center for Advanced Research of Energy and Materials, Hokkaido University, Kita 13 Nishi 8, Kita-Ku, Sapporo, 060-8628 Japan \\ ${ }^{2}$ Graduate School of Engineering, Hokkaido University, Kita 13 Nishi 8, Kita-Ku, Sapporo, 060-8628 Japan
}

*Corresponding author:

tel: $+81-11-706-6842$

email:k_abe@eng.hokudai.ac.jp

Received: October 11, 2018

Accepted: December 26, 2018

DOI: $10.22146 / \mathrm{ijc} .38359$

\begin{abstract}
Combustion synthesis (CS) is a simple and very fast method to synthesize a target material. New ironmaking method via the CS using carbon-infiltrated iron ore was proposed, and the possible conditions for the method were investigated. Adiabatic flame temperatures (Tad) of the CS reaction, maximum reachable temperatures in an adiabatic system, were calculated to estimate the sample temperature during the CS. To reach the adiabatic temperature of $1811 \mathrm{~K}, 23.9,27.9$, and $29.3 \mathrm{wt} . \%-\mathrm{C}$ were required for $\mathrm{Fe}_{2} \mathrm{O}_{3}$, $\mathrm{Fe}_{3} \mathrm{O}_{4}$, and $\mathrm{FeO}$, respectively. When the carbon amount is higher than the calculated one, molten iron which is separated from slag components should be obtained via the CS.
\end{abstract}

Keywords: combustion synthesis; ironmaking; goethite; adiabatic flame temperature; calculation

\section{- INTRODUCTION}

Goethite $(\alpha-\mathrm{FeOOH})$ based ores become nanoporous when they were mildly calcined [1-6]. Carbon infiltrated goethite ore has been produced via chemical vapor infiltration (CVI) method [7-14] using nanoporous $\mathrm{FeOOH}$ ore and tar vapor from coal or biomass. Fig. 1 shows the schematic illustration of the CVI process. Reduction of the carbon infiltrated goethite ore occurs at comparatively low temperature because (1): the deposited carbon is reactive amorphous carbon and (2): close contact between the goethite ore and the deposited carbon is reachable through nanopores of calcined goethite ore [13-14]. The dominant reduction reaction of the carbon infiltrated iron ore is direct reduction $\left(\mathrm{FeO}_{\mathrm{x}}+\mathrm{xC} \rightarrow \mathrm{Fe}+\mathrm{xCO}\right)$ because of the nanoordered close contact between ore and carbon [14-15]. This reduction reaction is a large endothermic reaction, and the additional heat source is needed to complete the reaction. When carbon amount in the carbon infiltrated ore exceeds this value, combustion of the excess carbon can be utilized as a heat source for the reduction reactions. When the exothermic heat from the carbon combustion is dominant, the total reaction (carbon combustion + iron oxide reduction) can self-propagate to complete "combustion synthesis".

Combustion synthesis (CS) is a simple and fast method using strong exothermic heat to synthesize a target material. A variety of materials have been synthesized via the CS method [16-19]. Fig. 2 illustrates the concept of CS. CS starts when one end of the raw materials is ignited and combustion wave selfpropagates from one end to the other. The CS reaction finishes automatically, resulting in the very fast process to get a target material. And the apparatus can be simple; only a part for ignition is needed.

We have already tried CS ironmaking using carbon-infiltrated goethite ore and the product was partially metalized after only $1 \mathrm{~min}$. experiment in an oxygen atmosphere [20]. Some experiments have been tried, however, the appropriate conditions for the preparation of the carbon-infiltrated ore have not been studied yet. The purpose of this study is to construct the concept of new ironmaking method using CS and to investigate the possible conditions of the CS ironmaking. 


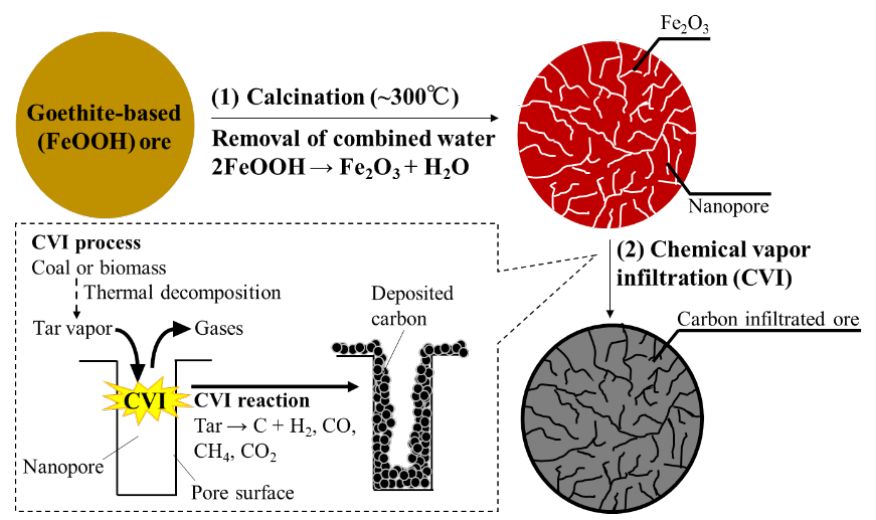

Fig 1. Schematic illustration of the chemical vapor infiltration (CVI) process

\section{- CALCULATION DETAILS}

A thermodynamic software (HSC Chemistry 5) [21] was used for thermodynamic calculations, and the adiabatic flame temperatures were calculated by a numerical software (MATLAB). The adiabatic flame temperature $\left(\mathrm{T}_{\mathrm{ad}}\right)$ is a maximum reachable temperature under the assumption of the adiabatic system. Iron ore contains slag components such as $\mathrm{Al}_{2} \mathrm{O}_{3}$ and $\mathrm{SiO}_{2}$, and they should be separated from the product iron. When the temperature of the product iron is over its melting point $(1811 \mathrm{~K})$, the iron can be separated from the slag components by gravitational power. That is why the conditions that the adiabatic flame temperature of the CS reaction is over $1811 \mathrm{~K}$ were investigated.

$\mathrm{T}_{\mathrm{ad}}$ of a combustion synthesis reaction can be calculated by the following equation:

$$
-\Delta \mathrm{H}=\int_{298}^{\mathrm{T}_{\mathrm{ad}}} \mathrm{C}_{\mathrm{p}} \mathrm{dT}+\Sigma \Delta \mathrm{H}_{\mathrm{t}}
$$

where $\Delta \mathrm{H}$ is the standard enthalpy change of the reaction $\left(\mathrm{J} \mathrm{mol}^{-1}\right), \mathrm{C}_{\mathrm{p}}$ is the specific heat capacity of a product $(\mathrm{J}$ $\mathrm{mol}^{-1} \mathrm{~K}^{-1}$ ), and $\Delta \mathrm{Ht}$ is the enthalpy change of phase transformation $\left(\mathrm{J} \mathrm{mol}^{-1}\right)$. The $\mathrm{T}_{\mathrm{ad}}$ calculations in this study were taken place at every $\mathrm{x}$ and $\mathrm{y}$. The following conditions and assumptions were used for the calculations. The starting materials were one molar $\mathrm{FeO}_{\mathrm{x}}$ $(\mathrm{x}=1-1.5)$, $\mathrm{y}$ molar carbon $(\mathrm{y}>1)$, and oxygen. Calculations were taken place at the step size of 0.01 from 0 until 1.5 for $\mathrm{x}$ and at the step size of 0.02 from 1 until 4 for $y$. The starting iron oxides were only monophase or

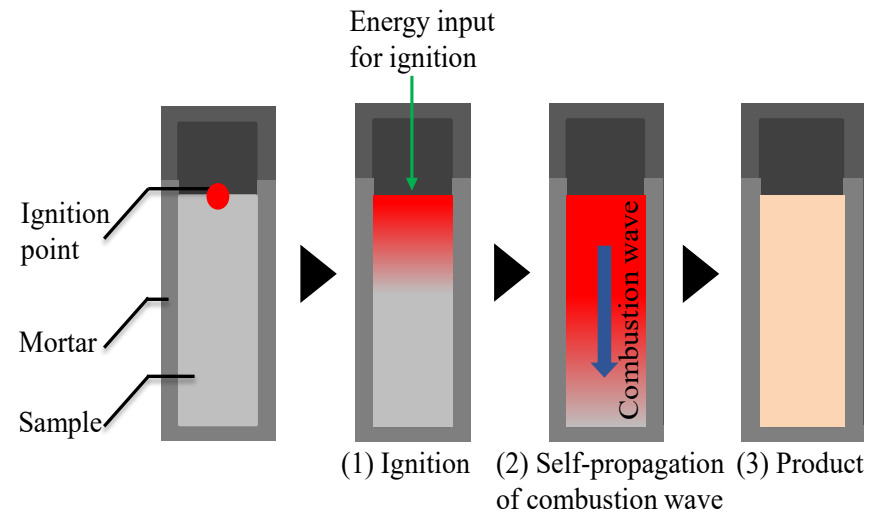

Fig 2. Schematic illustration of general combustion synthesis (CS)

biphase; $\mathrm{Fe} / \mathrm{FeO}$ at $0<\mathrm{x}<1, \mathrm{Fe}_{3} \mathrm{O}_{4} / \mathrm{FeO}$ at $1<\mathrm{x}<1.33$, and $\mathrm{Fe}_{3} \mathrm{O}_{4} / \mathrm{Fe}_{2} \mathrm{O}_{3}$ at $1.33<\mathrm{x}<1.5$. All the iron oxides were perfectly reduced to metallic iron and all the starting carbon was completely consumed during the reaction. The possible reactions for the combustion synthesis ironmaking were determined based on the results of thermodynamic calculations. The standard enthalpy changes of the reactions used in the calculations were as follows:

$$
\begin{aligned}
& \mathrm{C}+\mathrm{O}_{2} \rightarrow \mathrm{CO}_{2} \quad\left(\Delta \mathrm{H}=-394.36 \mathrm{~kJ} \mathrm{~mol}^{-1}\right) \\
& \mathrm{Fe}_{2} \mathrm{O}_{3}+3 \mathrm{C} \rightarrow 2 \mathrm{FE}+3 \mathrm{CO} \quad\left(\Delta \mathrm{H}=329.51 \mathrm{~kJ} \mathrm{~mol}^{-1}\right) \\
& \mathrm{Fe}_{3} \mathrm{O}_{4}+4 \mathrm{C} \rightarrow 3 \mathrm{Fe}+4 \mathrm{CO} \quad\left(\Delta \mathrm{H}=466.51 \mathrm{~kJ} \mathrm{~mol}^{-1}\right) \\
& \mathrm{FeO}+\mathrm{C} \rightarrow \mathrm{Fe}+\mathrm{CO} \quad\left(\Delta \mathrm{H}=108.55 \mathrm{~kJ} \mathrm{~mol}^{-1}\right)
\end{aligned}
$$

The enthalpy of melting of metallic iron was 13.815 $\left(\mathrm{kJ} \mathrm{mol}^{-1}\right)$. The specific heat, $\mathrm{C}_{\mathrm{p}}$, of a material is expressed as the following function of temperature $\mathrm{T}$ : $\mathrm{C}_{\mathrm{p}}=\mathrm{a}+\mathrm{bT}+\mathrm{cT}+\mathrm{dT}^{2}$

The following Table 1 (a-c) shows the thermodynamic data ( $a, b, c$, and $d$ values) for the specific heat of the products $\left(\mathrm{Fe}, \mathrm{CO}\right.$, and $\left.\mathrm{CO}_{2}\right)$ [22-29].

\section{- RESULTS AND DISCUSSION}

\section{Thermodynamic Calculations}

To determine what reaction is dominant in the CS ironmaking, we conducted thermodynamic calculations by Gibbs energy minimization method, which is general approach for chemical equilibrium model, before $\mathrm{T}_{\mathrm{ad}}$ 
Table 1. Specific heat $\left(\mathrm{C}_{\mathrm{p}}=\mathrm{a}+\mathrm{bT}+\mathrm{cT}^{-2}+\mathrm{dT}^{2}\right)$ of $(\mathrm{A}) \mathrm{Fe},(\mathrm{B}) \mathrm{CO}$, and $(\mathrm{C}) \mathrm{CO}_{2}[22-29]$

\begin{tabular}{lllll}
\hline (a) Fe & & & & \\
\hline Temperature range(K) & $\mathrm{a}$ & $\mathrm{b} \times 10^{3}$ & $\mathrm{c} \times 10^{-5}$ & $\mathrm{~d} \times 10^{6}$ \\
\hline $298-800$ & 31.873 & -22.333 & -3.519 & 40.076 \\
$800-1142$ & 930.624 & -1445.326 & -1077.585 & 676.725 \\
$1142-1184$ & -13469.674 & 15857.405 & 29209.382 & -5241.395 \\
$1184-1667$ & 24.717 & 7.463 & -1.700 & 0.368 \\
$1667-1811$ & -10.634 & 30.936 & 275.166 & -3.791 \\
$1811-$ & 46.000 & 0.000 & 0.000 & 0.000 \\
\hline (b) CO & & & & \\
\hline Temperature range(K) & $\mathrm{a}$ & $\mathrm{b} \times 10^{3}$ & $\mathrm{c} \times 10^{-5}$ & $\mathrm{~d} \times 10^{6}$ \\
\hline $298-800$ & 25.867 & 6.508 & 1.105 & 1.020 \\
$800-2200$ & 29.932 & 5.415 & -10.813 & -1.054 \\
$2200-$ & 37.178 & 0.203 & -54.490 & 0.004 \\
\hline (c) CO 2 & & & & \\
\hline Temperature range(K) & $\mathrm{a}$ & $\mathrm{b} \times 10^{3}$ & $\mathrm{c} \times 10^{-5}$ & $\mathrm{~d} \times 10^{6}$ \\
\hline $298-900$ & 29.314 & 39.970 & -2.484 & -14.783 \\
$900-2700$ & 54.435 & 5.116 & -43.578 & -0.806 \\
$2700-7600$ & 76.000 & -5.214 & -350.714 & 0.640 \\
\hline
\end{tabular}

calculations [30]. Fig. 3 shows the most stable chemical compositions at each temperature for the following cases; (A): carbon combustion reactions and (B): carbon reduction of $\mathrm{Fe}_{2} \mathrm{O}_{3}$. The thermodynamic calculations took place from $773 \mathrm{~K}$ to $2273 \mathrm{~K}$ at every $10 \mathrm{~K}$. The considered starting materials for $(\mathrm{A})$ were one molar $\mathrm{C}$ and one molar $\mathrm{O}_{2}$, and for (B) were one molar $\mathrm{Fe}_{2} \mathrm{O}_{3}$ and three molar C.

$\mathrm{CO}_{2}$ production was much higher than $\mathrm{CO}$ production in the carbon combustion reactions. Carbon combustion reactions were mainly divided into complete combustion $\left(\mathrm{C}+\mathrm{O}_{2} \rightarrow \mathrm{CO}_{2}\right)$ and incomplete combustion $\left(2 \mathrm{C}+\mathrm{O}_{2} \rightarrow 2 \mathrm{CO}\right)$. The result of the thermodynamic calculations implied the complete combustion reaction was dominant in the carbon combustion reactions.

$\mathrm{Fe}$ and $\mathrm{CO}$ were dominant in the carbon reduction of $\mathrm{Fe}_{2} \mathrm{O}_{3}$ at temperatures higher than $1800 \mathrm{~K}$. Carbon reduction of $\mathrm{Fe}_{2} \mathrm{O}_{3}$ are categorized into two reactions; direct reduction $\left(\mathrm{Fe}_{2} \mathrm{O}_{3}+3 \mathrm{C} \rightarrow 2 \mathrm{Fe}+3 \mathrm{CO}\right)$ and indirect reaction $\left(\mathrm{Fe}_{2} \mathrm{O}_{3}+3 \mathrm{CO} \rightarrow 2 \mathrm{Fe}+3 \mathrm{CO}_{2}\right)$ [15]. The indirect reaction occurs by $\mathrm{CO}$ which is generated from the direct reduction or Boudouard reaction $\left(\mathrm{C}+\mathrm{CO}_{2} \rightarrow\right.$ $2 \mathrm{CO}$ ). The result of the thermodynamic calculation implied the direct reduction reaction was dominant in the carbon reduction of iron oxides.
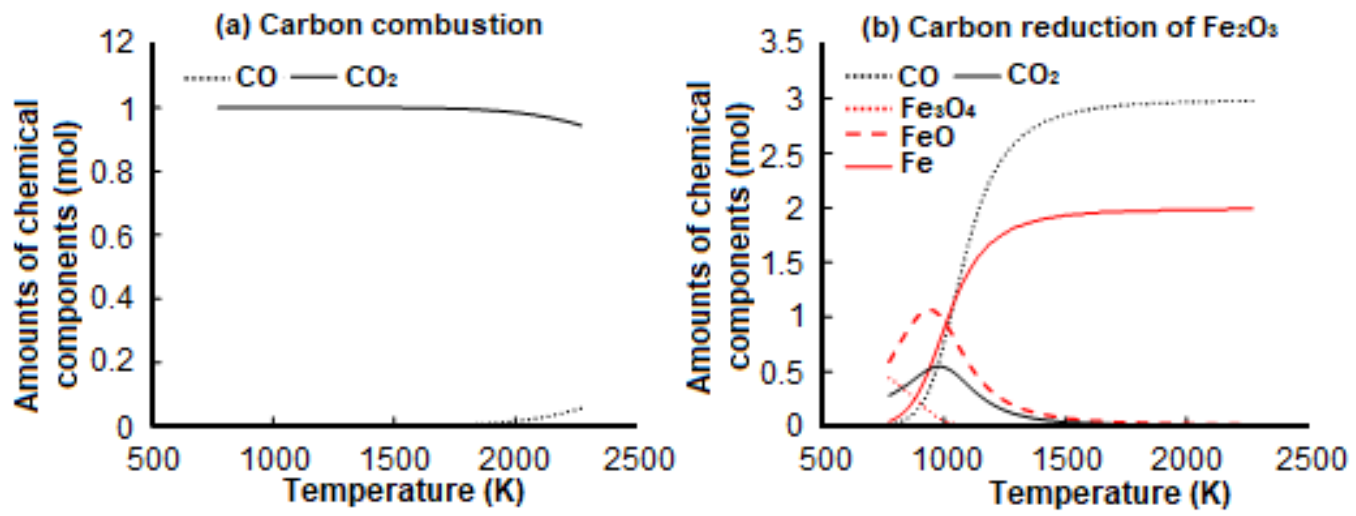

Fig 3. Chemical equilibrium calculations for (a) carbon combustion reactions and (b) carbon reduction reactions of $\mathrm{Fe}_{2} \mathrm{O}_{3}$ 


\section{Adiabatic Flame Temperature Calculations of the Combustion Synthesis Ironmaking}

Fig. 4 illustrates the proposed combustion synthesis ironmaking using the carbon-infiltrated goethite ore. The carbon-infiltrated goethite ore is covered by a thick carbon layer, and nano-ordered close contact between iron oxide and carbon occurs inside the ore [20]. When the carbon-infiltrated goethite ore is heated up in an oxygen atmosphere, combustion of the carbon layer occurs in the beginning. After that the exothermic heat from the combustion reaction transfers inside the ore where reduction of the ore is promoted.

In the last section, thermodynamic calculations revealed that the complete combustion reaction $\left(\mathrm{C}+\mathrm{O}_{2}\right.$ $\left.\rightarrow \mathrm{CO}_{2}\right)$ and the direct reduction reaction $\left(\mathrm{Fe}_{2} \mathrm{O}_{3}+3 \mathrm{C} \rightarrow\right.$ $2 \mathrm{Fe}+3 \mathrm{CO})$ were dominant at high temperatures. That was why we conducted $\mathrm{T}_{\mathrm{ad}}$ calculations in this section under the assumption that the other reactions were negligible. The CS reactions consisted of combustion of carbon and reduction of iron oxides. In the reduction reaction, one molar iron oxide $\left(\mathrm{FeO}_{\mathrm{x}}\right)$ was reduced by $\mathrm{x}$ molar carbon;

$\mathrm{FeO}_{\mathrm{x}}+\mathrm{xC} \rightarrow \mathrm{Fe}+\mathrm{xCO}$

The remaining carbon was combusted by oxygen for a heat source;

$(\mathrm{y}-\mathrm{c}) \mathrm{C}+(\mathrm{y}-\mathrm{x}) \mathrm{O}_{2} \rightarrow(\mathrm{y}-\mathrm{x}) \mathrm{CO}_{2}$

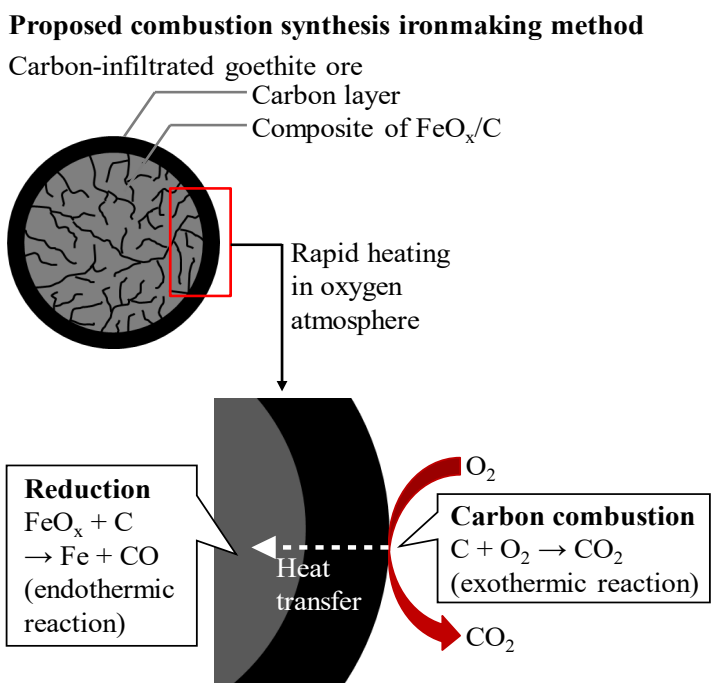

Fig 4. Illustration of the proposed combustion synthesis ironmaking method
Thus, the total CS reaction considered in this study was:

$\mathrm{FeO}_{\mathrm{x}}+\mathrm{yC}+(\mathrm{y}-\mathrm{x}) \mathrm{O}_{2} \rightarrow \mathrm{Fe}+\mathrm{xCO}+(\mathrm{y}-\mathrm{x}) \mathrm{CO}_{2}\left(\Delta \mathrm{H}_{\mathrm{CS}}\right)$

Above $1811 \mathrm{~K}$, product iron should be molten,

$\mathrm{Fe}(\mathrm{s}) \rightarrow \mathrm{Fe}(\mathrm{l}) \quad\left(\Delta \mathrm{H}_{\mathrm{t}}\right)$

where, $\Delta \mathrm{H}_{\mathrm{CS}}$ and $\Delta \mathrm{H}_{\mathrm{t}}$ means standard enthalpy changes of the total CS reaction (eq. (9)) and the melting reaction (eq. (10)), respectively.

The adiabatic flame temperature can be calculated for the eq. (9) by the following equation.

$-\Delta \mathrm{H}_{\mathrm{CS}}=\int_{298}^{\mathrm{T}_{\mathrm{ad}}}\left\{\left(\mathrm{C}_{\mathrm{p}}(\mathrm{Fe})+\mathrm{xC}_{\mathrm{p}}(\mathrm{CO})+(\mathrm{y}-\mathrm{x}) \mathrm{C}_{\mathrm{p}}\left(\mathrm{CO}_{2}\right)\right\} \mathrm{dT}+\Delta \mathrm{H}_{\mathrm{t}}\right.$

The eq. (11) was numerically solved according to the trapezoidal rule combined with trial and error to find $\mathrm{T}_{\mathrm{ad}}$.

Fig. 5 shows a three-dimensional image of the calculated adiabatic temperatures at every $\mathrm{x}$ and $\mathrm{y}$ value. Lower $\mathrm{x}$ and higher $\mathrm{y}$ values made the adiabatic temperatures higher. That was because the fractions of reduction reaction (endothermic) and carbon combustion reaction (exothermic) got higher at lower $\mathrm{x}$ and higher $\mathrm{y}$ values. A gap was seen at the adiabatic temperature of $1811 \mathrm{~K}$; the melting point of metallic iron.

The required carbon amounts in the carbon infiltrated iron ore to synthesize molten iron via CS are

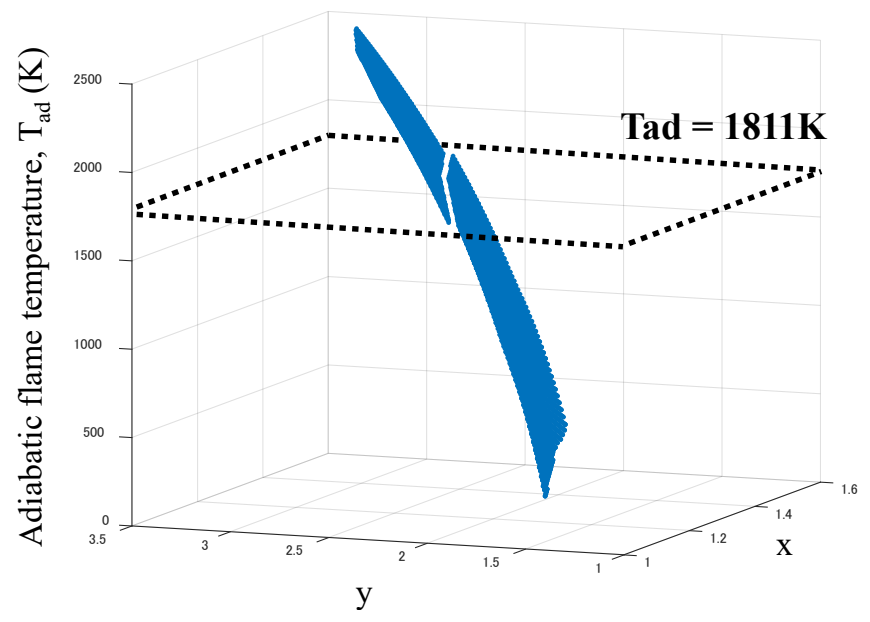

Fig 5. Three-dimensional expression of the adiabatic flame temperatures $\left(\mathrm{T}_{\mathrm{ad}}\right)$ of the combustion synthesis reaction at every $\mathrm{x}$ and $\mathrm{y}$ value 


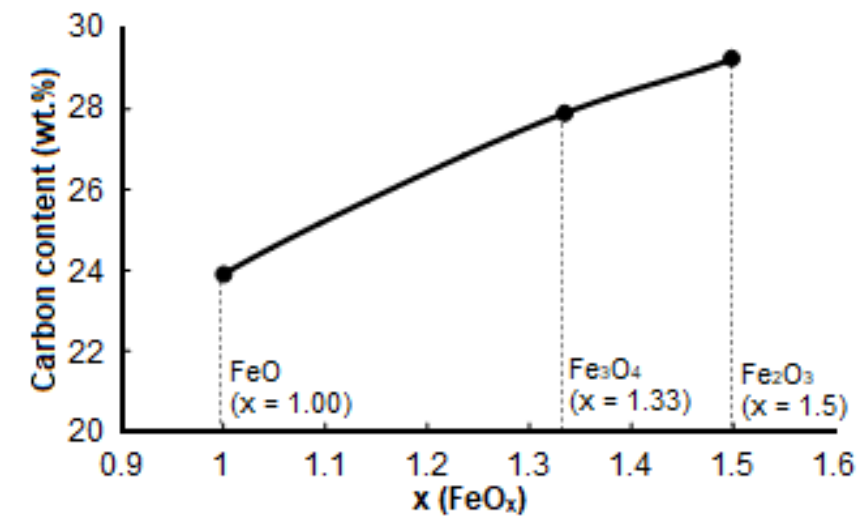

Fig 6. Required carbon content in carbon infiltrated iron oxides $\left(\mathrm{C} / \mathrm{FeO}_{\mathrm{x}}\right)$ to obtain molten iron $(1811 \mathrm{~K})$ via combustion synthesis

shown in Fig. 6. The required carbon amount was the highest (29.3 wt.\%) when $\mathrm{Fe}_{2} \mathrm{O}_{3}(\mathrm{x}=1.5)$ was the starting iron oxide. The partial reduction of the starting iron oxide reduced the required carbon amount; 27.9 and 23.9 wt.\% of carbon was required for $\mathrm{Fe}_{3} \mathrm{O}_{4}$ and $\mathrm{FeO}$. The reduction of iron oxides was a strong endothermic reaction that was why much more heat thermal compensation was needed for $\mathrm{Fe}_{2} \mathrm{O}_{3}$. Overall, 23.9-29.3 wt.\% of carbon was required in the carbon-infiltrated iron oxides to obtain molten metallic iron via CS. Carbon contents of the carboninfiltrated goethite ore which was prepared by the CVI process have reached a maximum of $5 \mathrm{wt} . \%$ [11-12], however, the maximal value is far from the required one calculated in this study. In the CVI process, tar vapor diffuse in the nanopores of the goethite ore, then, carbon deposition occurs at the wall of the nanopores. When the operation temperature is too high, the deposition reaction should be much faster than the diffusion, resulting in carbon deposition only at the surface of the ore [13]. When the temperature low, the deposition reaction should be very slow and it takes quite long time to get high amount of carbon [13]. That is the reason that optimization of the condition is important for the CVI process to obtain carbon-infiltrated goethite ore with high carbon contents. Tar-impregnation method, on the other hand, can easily control the amount of deposited carbon [20,31]. 23.9-29.3 wt.\% of deposited carbon should be easily reached using this method.

\section{- CONCLUSION}

In this study, calculations of adiabatic flame temperatures $\left(\mathrm{T}_{\mathrm{ad}}\right)$ for combustion synthesis (CS) ironmaking were conducted. The carbon contents and the starting iron oxides in the carbon-infiltrated ore were selected as parameters. They were variously changed and the $\mathrm{T}_{\mathrm{ad}}$ was calculated at every point.

The considered reactions for the $\mathrm{T}_{\mathrm{ad}}$ calculations were perfect carbon combustion $\left(\mathrm{C}+\mathrm{O}_{2} \rightarrow \mathrm{CO}_{2}\right)$ and direct reduction $\left(\mathrm{FeO}_{\mathrm{x}}+\mathrm{C} \rightarrow \mathrm{Fe}+\mathrm{CO}\right)$ reactions; they were the dominant reactions in chemical equilibrium conditions.

As well as reduction of iron oxides, separation of metallic iron from slag components is also needed to obtain pure iron. The required carbon amounts in carbon-infiltrated iron oxides were calculated at the condition of Tad higher than $1811 \mathrm{~K}$; the melting point of metallic iron. The strong exothermic, carbon combustion reaction compensated the exothermic heat of reduction and melting reactions and the sensible heat of the products. Pre-reduction of iron oxide reduce the required carbon amount. The minimum carbon requirement for iron oxide was 23.9-29.3 wt.\%. The results provide a guide for preparation of raw material for the proposed CS ironmaking.

\section{- ACKNOWLEDGMENTS}

This study was supported by the Grant-in-Aid for Research Fellow of Japan Society for the Promotion of Science (JSPS).

\section{- REFERENCES}

[1] Naono, H., Nakai, K., Sueyoshi, T., and Yagi, H., 1987, Porous texture in hematite derived from goethite: Mechanism of thermal decomposition of geothite, J. Colloid Interface Sci., 120 (2), 439-450.

[2] Rendon, J.L., Cornejo, J., de Arambarri, P., and Serna, C.J., 1983, Pore structure of thermally treated goethite ( $\alpha-\mathrm{FeOOH})$, J. Colloid Interface Sci., 92 (2), 508-516.

[3] Meng, F., Morin, S.A., and Jin, S., 2011, Rational solution growth of $\alpha-\mathrm{FeOOH}$ nanowires driven by 
screw dislocations and their conversion to $\alpha-\mathrm{Fe}_{2} \mathrm{O}_{3}$ nanowires, J. Am. Chem. Soc., 133 (22), 8408-8411.

[4] Saito, G., Nomura, T., Sakaguchi, N., and Akiyama, T., 2016, Optimization of the dehydration temperature of goethite to control pore morphology, ISIJ Int., 56 (9), 1598-1605.

[5] Abe, K., Saito, G., Nomura, T., and Akiyama, T., 2016, Limonitic laterite ore as a catalyst for the dry reforming of methane, Energy Fuels, 30 (10), 8457-8462.

[6] Abe, K., Kurniawan, A., Nomura, T., and Akiyama, T., 2018, Effects of reduction on the catalytic performance of limonite ore, J. Energy Chem., 27 (5), 1489-1495.

[7] Hata, Y., Purwanto, H., Hosokai, S., Jun-Ichiro, H., Kashiwaya, Y., and Akiyama, T., 2009, Biotar ironmaking using wooden biomass and nanoporous iron ore, Energy Fuels, 23 (2), 1128-1131.

[8] Rozhan, A.N., Cahyono, R.B., Yasuda, N., Nomura, T., Hosokai, S., Purwanto, H., and Akiyama, T., 2012, Carbon deposition from biotar by fast pyrolysis using the chemical vapor infiltration process within porous low-grade iron ore for iron-making, Energy Fuels, 26 (12), 7340-7346.

[9] Cahyono, R.B., Rozhan, A.N., Yasuda, N., Nomura, T., Hosokai, S., Kashiwaya, Y., and Akiyama, T., 2013, Catalytic coal-tar decomposition to enhance reactivity of low-grade iron ore, Fuel Process. Technol., 113, 84-89.

[10] Cahyono, R.B., Rozhan, A.N., Yasuda, N., Nomura, T., Purwanto, H., and Akiyama, T., 2013, Carbon deposition using various solid fuels for ironmaking applications, Energy Fuels, 27 (5), 2687-2692.

[11] Cahyono, R.B., Yasuda, N., Nomura, T., and Akiyama, T., 2014, Optimum temperatures for carbon deposition during integrated coal pyrolysis-tar decomposition over low-grade iron ore for ironmaking applications, Fuel Process. Technol., 119, 272-277.

[12] Kurniawan, A., Abe, K., Nomura, T., and Akiyama, T., 2018, Integrated pyrolysis-tar decomposition over low-grade iron ore for ironmaking applications: Effects of coal-biomass fuel blending, Energy Fuels, 32 (1), 396-405.
[13] Cahyono, R.B., Saito, G., Yasuda, N., Nomura, T., and Akiyama, T., 2014, Porous ore structure and deposited carbon type during integrated pyrolysistar decomposition, Energy Fuels, 28 (3), 2129-2134.

[14] Hosokai, S., Matsui, K., Okinaka, N., Ohno, K.I., Shimizu, M., and Akiyama, T., 2012, Kinetic study on the reduction reaction of biomass-tar-infiltrated iron ore, Energy Fuels, 26 (12), 7274-7279.

[15] Kashiwaya, Y., Yamaguchi, Y., Kinoshita, H., and Ishii, K., 2007, In situ observation of reduction behavior of hematite with solid carbon and crystallographic orientation between hematite and magnetite, ISIJ Int., 47 (2), 226-233.

[16] Abe, K., Kikuchi, A., Okinaka, N., and Akiyama, T., 2014, Single thermite-type combustion synthesis of $\mathrm{Fe}_{2} \mathrm{VAl}$ for thermoelectric applications from $\mathrm{Fe}$, $\mathrm{V}_{2} \mathrm{O}_{5}$ and $\mathrm{Al}$ powders, J. Alloys Compd., 611, 319-323.

[17] Morsi, K., 2001, Review: Reaction synthesis processing of $\mathrm{Ni}-\mathrm{Al}$ intermetallic materials, Mater. Sci. Eng., A, 299 (1-2), 1-15.

[18] Holt, J.B., and Munir, Z.A., 1986, Combustion synthesis of titanium carbide: Theory and experiment, J. Mater. Sci., 21 (1), 251-259.

[19] Lin, S., and Selig, J., 2010, Self-propagating hightemperature synthesis of $\mathrm{Ca}_{1.24} \mathrm{Co}_{1.62} \mathrm{O}_{3.86}$ thermoelectric powders, J. Alloys Compd., 503 (2), 402-409.

[20] Abe, K., Kurniawan, A., Ohashi, K., Nomura, T., and Akiyama, T., 2018, Ultrafast iron-making method: Carbon combustion synthesis from carbon-infiltrated goethite ore, ACS Omega, 3 (6), 6151-6157.

[21] Roine, A., 2002, HSC Chemistry Version 5.1, Outotec Research Oy, Helsinki, Finland.

[22] National Institute of Standards and Technology, 1998, NIST-JANAF Thermochemical Tables, $4^{\text {th }}$ ed., Eds., Chase, M.W., American Chemical Society, Washington, DC.

[23] Scientific Group Thermodata Europe, 1999, Thermodynamic Properties of Inorganic Materials, Springer Verlag, Berlin, Germany.

[24] McBride, B.J., Gordon, S., and Reno, M.A., 2001, Thermodynamic Data for Fifty Reference Elements, 
National Aeronautics and Space Administration, Washington, DC.

[25] Knacke, O., Kubaschewski, O., and Hesselmann, K., 1991, Thermochemical Properties of Inorganic Substances, $2^{\text {nd }}$ ed., Springer Verlag, Berlin, Germany.

[26] Bard, A.J., Parsons, R., and Jordan, J., 1985, Standard Potentials in Aqueous Solution, $1^{\text {st }}$ ed., Marcel Dekker, New York.

[27] Barin, I., 1995, Thermochemical Data of Pure Substances, $1^{\text {st }}$ ed., Wiley-VCH Verlag GmbH \& Co. KGaA, Weinheim.

[28] Frenkel, M., Kabo, G.J., Marsh, K.N., Roganov, G.N., and Wilhoit, R.C., 1994, Thermodynamics of Organic Compounds in the Gas State, Volume II, CRC Press, Boca Raton, FL.
[29] National Institute of Standards and Technology, 1990, JANAF Thermochemical Tables, $3^{\text {rd }}$ ed., American Chemical Society, Washington, DC.

[30] Li, X., Grace, J.R., Watkinson, A.P., Lim, C.J., and Ergüdenler, A., 2001, Equilibrium modeling of gasification: a free energy minimization approach and its application to a circulating fluidized bed coal gasifier, Fuel, 80 (2), 195-207.

[31] Mochizuki, Y., Nishio, M., Ma, J., Tsubouchi, N., and Akiyama, T., 2016, Preparation of carboncontaining iron ore with enhanced crushing strength from limonite by impregnation and vapor deposition of tar recovered from coke oven gas, Energy Fuels, 30 (8), 6233-6239. 